\title{
Nikolaus Rungius: Lifestyle and Status of an Early Seventeenth-Century Northern Finnish Vicar
}

\author{
Tiina Väre • Sanna Lipkin • Jenni A. Suomela • \\ Krista Vajanto
}

\begin{abstract}
Vicar Nikolaus Rungius's (ca. 1560-1629) mummified remains have been the subject of research that has provided a wide variety of information on his life. This article examines the ways Rungius's health and lifestyle highlight his status as a vicar, and this status is visible in his burial and funerary clothing. He was a relatively large man for his time. CT scans even include indications of certain conditions related to being overweight. Likewise, stable-isotope analyses of his nail keratin support the hypothesis that he was consuming a rather heavy, protein-rich diet. Given his status as the vicar of Kemi parish in northern Finland, he likely made sumptuous use of the rich local natural resources of fish, game, and domestic animals as part of his regular diet. In addition to his diet and health, the vicar's high-quality clothes, while fragmentary, also open an avenue to extend the exploration of his social status and wealth.
\end{abstract}

T. Väre $(\bowtie)$

Department of Archaeology/Cancer Research and Translational Medicine Research Unit, University of Oulu, Pentti Kaiteran katu 1, Linnanmaa, PL 8000, FI-90014 Oulu, Finland e-mail: tiina.vare@oulu.fi

S. Lipkin

Department of Archaeology, University of Oulu, Pentti Kaiteran katu 1, Linnanmaa, PL 8000, FI-90014 Oulu, Finland

\section{J. A. Suomela}

Department of Education/Craft Studies, University of Helsinki, PO Box 8 (Siltavuorenpenger 10), FI-00014 Helsinki, Finland

\section{K. Vajanto}

Nanomicroscopy Center, Aalto University, Puumiehenkuja 2 (door H), FI-02150 Espoo, Finland
Extracto Los restos momificados del vicario Nikolaus Rungius (ca. 1560-1629) han sido objeto de investigaciones que han proporcionado una amplia variedad de información sobre su vida. Este artículo examina las formas en que la salud y el estilo de vida de Rungius destacan su condición de vicario, y esta condición es visible en su entierro y vestimenta funeraria. Era un hombre relativamente grande para su época. Las tomografías computarizadas incluso incluyen indicaciones de ciertas condiciones relacionadas con el sobrepeso. Del mismo modo, los análisis de isótopos estables de la queratina de sus uñas apoyan la hipótesis de que estaba consumiendo una dieta bastante pesada y rica en proteínas. Dado su estatus como vicario de la parroquia de Kemi en el norte de Finlandia, probablemente hizo un uso suntuoso de los ricos recursos naturales locales de pescado, caza y animales domesticados como parte de su dieta regular. Además de su dieta y salud, la ropa de alta calidad del vicario, aunque fragmentaria, también abre una vía para ampliar la exploración de su estatus social y riqueza.

Résumé Les restes mommifiés du pasteur Nikolaus Rungius (entre 1560 et 1629) ont fait l'objet d'une recherche ayant apporté une grande variété d'informations sur sa vie. Cet article examine la manière dont la santé et le mode de vie de Rungius mettent en évidence son statut de pasteur, ce dernier ressortant de son enterrement et des vêtements funéraires. Il était d'une corpulence relativement importante pour son époque. La tomodensitométrie comporte même des indications de certaines pathologies liées au fait d'être en surpoids. 
De même, les analyses d'isotope stable de la kératine de son ongle viennent confirmer l'hypothèse qu'il avait un régime alimentaire plutôt abondant et riche en protéines. Compte tenu de son statut de pasteur pour la paroisse de Kemi dans la Finlande septentrionale, il devait tirer largement parti des copieuses ressources naturelles locales composées de poisson, gibier et animaux domestiques dans le cadre de son régime alimentaire habituel. Outre son alimentation et sa santé, les vêtements de grande qualité du pasteur, s'ils sont fragmentaires, ouvrent également une piste afin d'élargir l'étude de son statut social et de sa fortune.

Keywords mummy research · early modernity · textile archaeology $\cdot$ Finland $\cdot$ paleopathology $\cdot$ stable isotopes

\section{Introduction}

During the early 17 th century, Kemi was a geographically large parish at the northeastern edge of the Swedish kingdom, now northern Finland (Fig. 1). Kemi parish functioned quite independently, with only occasional visits and inspections from the bishop of Turku. In the 1610s, Bishop Erik Sorolainen appointed Nikolaus Rungius (ca. 1560-1629) as the vicar of Kemi parish, which Rungius went on to lead for approximately 15 years (Vahtola 1997b:152-156). After his death, his remains were buried beneath the old stone church of Keminmaa, St. Michael's Church. The remains mummified naturally. This eventually made his corpse famous, and his preservation enabled our investigation into his health, nutrition, and clothing.

In 2011, the mummified remains of Vicar Rungius were imaged at Oulu University Hospital utilizing computed-tomography (CT) scanning (Fig. 2). The purpose was not only to examine the mummy's preservation, but also the vicar's body proportions and state of health at the time of his death. To further explore his diet, the data obtained from the CT scans were analyzed in conjunction with the stable carbon and nitrogen isotopes in the vicar's nail keratin. The results of this work have been previously published in both a series of articles and a dissertation study (S. Niinimäki et al. 2011; Väre, S. Niinimäki et al. 2011; Väre, Nuñez et al. 2015; Väre, Junno et al. 2016; Väre, J. Niinimäki et al. 2016; Väre 2017; Väre, Vilkama et al. 2017). In contrast, the studies concerning the vicar's funerary attire have been addressed only briefly (Lipkin et al. 2015). In this article, we use a slightly different framework to explore these results as projections of his social status as a professionally high-ranking individual in the early modern class society in northern Finland.

"Status" is defined here as the position or placement of an individual in relation to another or others, especially in regard to social standing. Status is a more flexible term than "rank," i.e., a group of individuals forming a class in a vertical social hierarchy. As concepts, status, rank, and class are interlinked and multiform (Weber 1978; Wright 1993), and their use in interpretation of material culture has proved to be useful (Babić 2005; Mrozowski 2006; Wurst 2006; Kuokkanen 2016).

Based on recent studies addressing the expressions of status in northern Finnish postmedieval communities, it may be concluded that Swedish 17th-century class society was multifaceted in terms of inhabitants' rank. For instance, Puputti (2009:51) found that the social control over the diets of people with different statuses may explain certain distribution patterns of the bones of animals consumed in the early modern town of Tornio. Salmi and Kuokkanen (2014) have also discussed the bodily practices associated with food and dress as a means of negotiating class identities in Oulu. Kuokkanen (2016) discusses the relationship between gender and class by analyzing the manifestation of identity through small clothing items, such as buttons, clasps, and belt buckles in 18th-century Oulu. Kuokkanen's research may be considered the first step to a better understanding and theorizing of the environment in which northern Finnish classes interacted and its archaeological interpretations. Seventeenth-century Swedish society was also manifold; while social ranks defined class society during the early 17 th century, many people did not belong to any of the four official classes: nobility, clergy, bourgeoisie, and peasants. Official and social ranks were different; for instance, holders of minor priestly offices belonged to the clergy in a social, but not parliamentary, sense. Social ranks were established, but not all members could exercise the political power of class. During the early 17 th century, nobility and clergy formed the higher social ranks. Only at the end of 18th century did some of the bourgeoisie achieve the same higher social rank. Peasants and people without established rank formed a large group of common people (Wirilander 1974:15-19,35-36; Kuokkanen 2016:30). 
Fig. 1 The Kemi parish formerly included the modern area of northernmost Finland (Finnish Lapland). (Drawing by $\mathrm{K}$. Vajanto, 2018.)

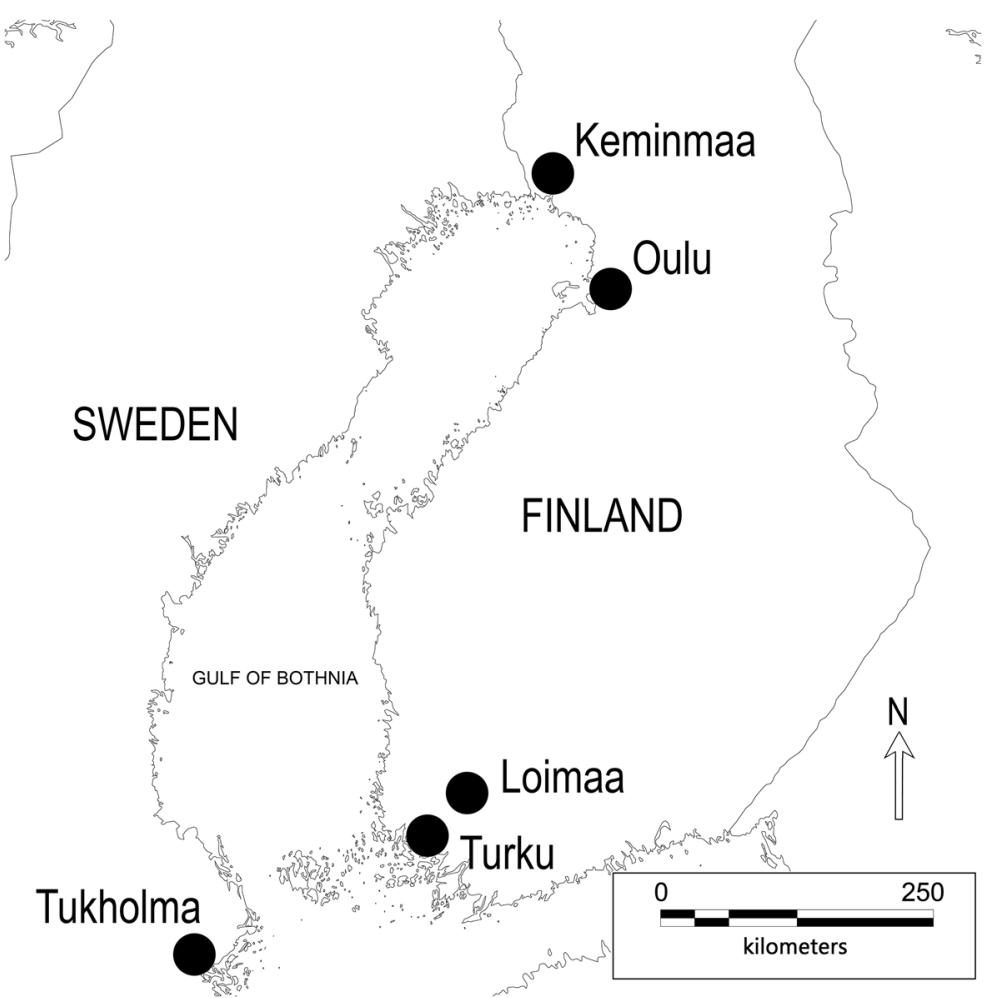

In this context, however, we prefer to use the term "social status" and look closely at Rungius's status as a vicar in his own northern parish and its importance among his parishioners and family. It is known that his official rank, regardless of his location at the edge of the kingdom, was among the highest in the society, and it may be assumed that his social rank was also the highest in his own community. It is important to acknowledge that, despite his origins in southwestern Finland, Rungius was sent as a priest to this faraway parish. This northern parish had both limited natural resources and a generally harsh environment. It should not be considered as an inherently negative posting, however, as Kemi parish was a large and desirable parish for its vicar, who typically could collect rather handsome tithes in such luxury products as fur and salmon (Hedman 1969:89-90).

One manner in which social hierarchy was established during the early modern period was through the division of burial sites. The most prestigious sites were located directly beneath the churches; those located by the chancel at the east of the building were particularly highly valued (Talve 1989; Lempiäinen 1990; Paavola 1998:173). Unsurprisingly, Vicar Rungius's burial site was beneath the floor of his home church. The practice of burial beneath churches, with the prevailing cold and well-ventilated environment beneath the church floors, is believed to have led to the mummification of the remains of some individuals (Núñez, Paavola et al. 2008).

\section{The Mummified Remains of Vicar Rungius}

Although not unique, the mummy of Vicar Nikolaus Rungius is probably the best-known example of mummification from graves beneath Finnish churches. After his death, Vicar Rungius's body was moved from one coffin to another at least four times, beginning as early as 1704. As such, the tradition of even the small-scale exhibition of his remains likely originates from the same century (Oulun maakunta-arkisto [OMA] 1700-1716; Borg 1944; Knihtilä 1982; Huurre 1983; Kallinen 1990; Väre 2017:49). Prior to the late 19th century, when the mummy's damaged state finally compelled the bishop to order the parish officials to place the remains under lock and key, they could, in fact, be freely visited at the vicar's original, high-ranking burial site by the chancel in the southeastern corner of the church (OMA 1728, 1862-1978; Cajanus 1927:28-29). It was only in the 
Fig. 2 Vicar Rungius's remains spontaneously mummified in his grave under the floor of his home church (St. Michael's Church, Keminmaa, Finland). (Photo by A. Kairakari, 2018.)

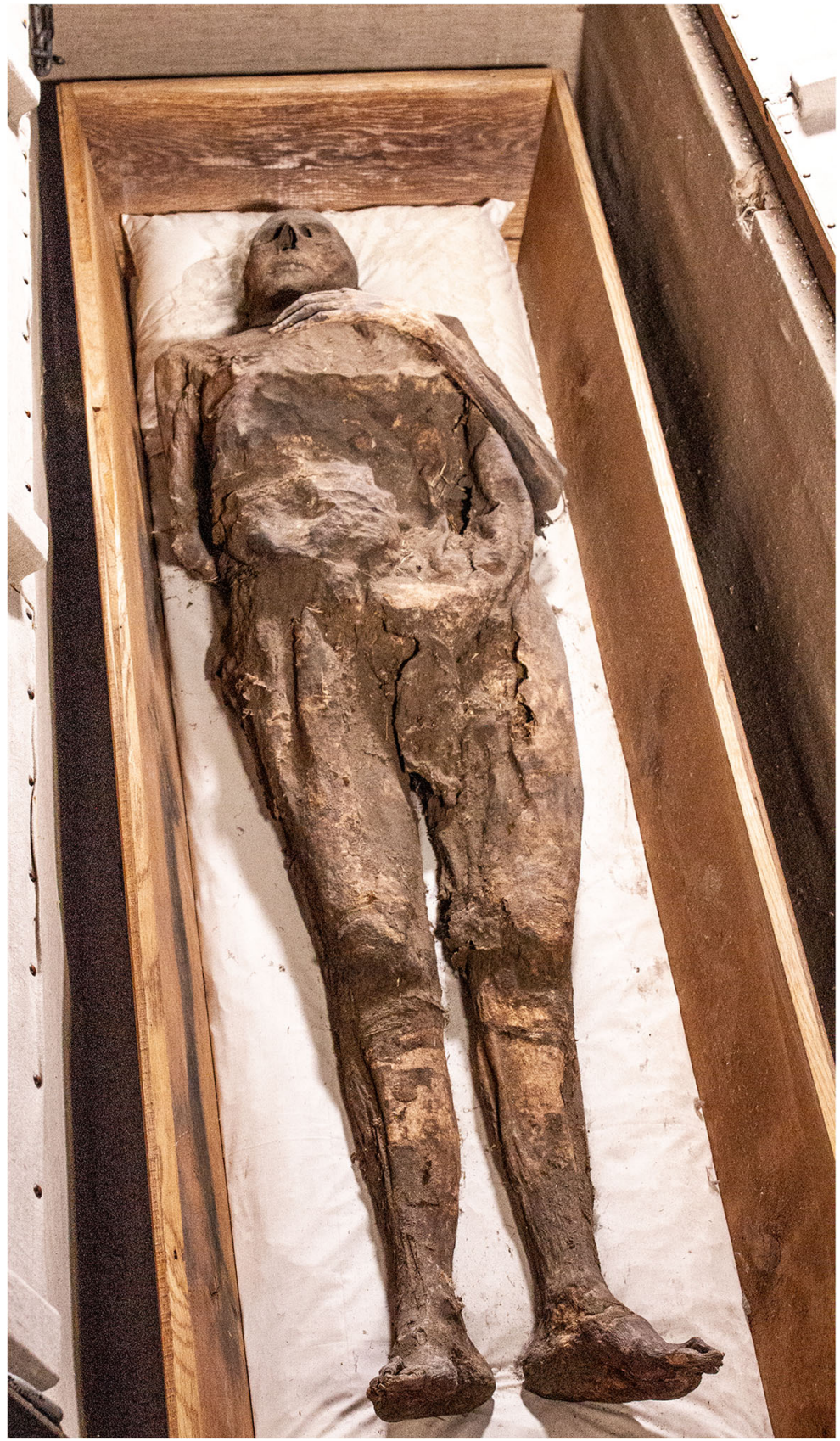

1930s that the remains were finally placed in their current glass-lidded coffin beneath a set of trapdoors in the church floor, enabling safe and easy exhibition (Huurre 1983; Kallinen 1990).

The mummy has preserved remarkably well considering it is nearly 400 years old and has been freely accessible to the public for most of its history. Some deterioration is observable. The mummy's missing right forearm was mentioned as early as the 1860 s, and our examination revealed that the head is no longer naturally attached to the torso (Calamnius 1868:201-202; Väre, Nuñez et al. 2015). Even though Rungius has mummified, his clothes have mostly decayed, which is unusual in comparison with similarly mummified human burials (Lipkin, Ruhl, Vajanto et al., this issue). Generally, as organic material, textiles are unlikely to preserve, but the 
conditions beneath the Keminmaa church floor that led to mummification have also preserved an unprecedented quantity of associated textile materials. The greater level of decay in this instance may be due to the fact that his body had been moved from the original old coffin to a series of new ones, a process that may also explain other damage noted, including the disarticulation of the head. Alternatively, poor preservation of his clothes may have been a partial result of the decomposition process prior to his burial. His viscera and brain, which typically decompose rather rapidly, were almost completely absent, perhaps suggesting that Rungius received a long death watch (Väre, Junno et al. 2016), which records indicate could last between one week and a full month for a priest (Regnard 1982:108; Paavola 1998:155,262). It is likely that Rungius's remains began to mummify only once he was buried beneath the well-ventilated church floor. It has been suggested that it is likely such mummification took place mostly during the winter months (Nuñéz, Paavola et al. 2008).

\section{A Clergyman's Child}

Vicar Rungius was a native of southern Finland, as were most priests in the north at the time. His family presumably owned a rather wealthy estate in Onkijoki, Loimaa, in southwestern Finland, near the two parishes in which his father and brother held vicars' posts (Hyötyniemi 1953; Hedman 1969:89-90; Vahtola 1997b:156-157; Väänänen 2011a). As a member of the family Rungius, guided by traditions in a class society, he would have quite naturally inclined toward an ecclesiastical career. He began his clerical career as a military priest in the Turku region, near his native Loimaa. Presumably late in the 16th century, he resettled on the west coast of Finland, where he worked as a chaplain, but soon proceeded farther north to become chaplain of the Kemi parish. As he subsequently married Helena, the daughter of the parish's vicar, Simon Nicolai Ruuth, Rungius's later inheritance of his father-in-law's post may have been expected. Once his father-in-law became increasingly frail due to old age, a number of the vicar's duties were entrusted to Rungius. After the elderly and sickly Vicar Ruuth died in the mid-1610s, his subordinate and son-in-law was consecrated the next vicar of Kemi (Cajanus 1927:90; Hyötyniemi 1953; Kallinen 1990; Vahtola 1997b:156; Väänänen 2011a, 2011b).
Being a chaplain was often synonymous with being the vicar's personal servant. They were typically dependent on the parishioners' good will and would seldom be as well off as the parish's vicar (Virrankoski 1973:678,683-684). It may still be assumed that Chaplain Rungius and his wife were already relatively wealthy in 1610, as they donated an unusually valuable painted pulpit to the Kemi parish (Vahtola 1997b:156). The most logical explanation for them being able to afford such a precious gift would be their position as a members of clergy families - particularly as the wife's father was already the vicar in the same parish.

\section{Rising in Rank, Becoming a Vicar}

Rungius's rise to vicar of the parish represented an improvement in his rank, although he had enjoyed relatively high status, and presumably wealth, all his life. After his consecration, he spent his last 15 years at the top of the local social hierarchy. Many early modern parishes - particularly in northern Finland-lacked members of the high nobility common elsewhere. As such, vicars typically were the most prestigious, and very often the richest, individuals in their communities, undoubtedly able to consume a much more versatile and ample diet than many of their parishioners (Virrankoski 1973:682-683,687; Regnard 1982:104). Although most of these parishes were not very hierarchical (Paavola 1998:119,263), for most parishioners everyday life was laborious. The harsh subarctic climate, with long, dark, and cold winters, and short, labile summers, surely challenged their ability to provide adequate food and other resources. During Vicar Rungius's tenure, ensuring subsistence was possibly even more demanding than usual, as it coincided with a period known as the "Little Ice Age," a period of long, cold winters and short, rainy summers (Virrankoski 1973:16,207,270; Vahtola 1997b:119).

The vicar, on the other hand, enjoyed the production of the fields and livestock associated with the vicarage. Typically, it was tax free and the largest estate in the parish. Additionally, his income was handsomely supplemented with the various tithes and commissions the parishioners were obliged to pay. In Kemi this consisted largely of fur and salmon, both valuable products. These tithes and commissions often constituted more than the vicarage itself could consume, and the surplus was exchanged in the marketplace. On top of that, the vicar's 
unique position, representing the link between the believers and God, further enhanced his status among the parishioners (Hedman 1969:89; Virrankoski 1973:679683,685-687). In Ostrobothnia, vicars were also known to buy goods from farmers, selling them at market for twice the price they paid. This way the vicars became very rich, and it was reflected in their consumption patterns and fashionable clothing. For instance, in 1558 Jaakko Geet, the vicar of Isokyrö, transported from Stockholm elaborate English and other foreign fabrics with his own ship for himself, his wife (skirt fabric was equal to the price of two horses), and servants. Vicars of large parishes were usually rich, and their assets were tied up in silver and other valuable items, such as jewelry (Pylkkänen 1955:360).

The holdings of early modern Kemi parish, 108,000 $\mathrm{km}^{2}$, nearly completely encompassed the area that is now Finnish Lapland (Vahtola 1997b:151; Hiekkanen 2014:508). Despite the often quite extreme weather conditions, the local environment could provide a livelihood for those able to avail themselves of its opportunities. For one thing, the River Kemi, running through Finnish Lapland, was a particularly rich source of fish, mainly salmon. This was true to such an extent that, until very recently, the local economy of Kemi, near the mouth of the river, was based on salmon (Vilkuna 1951, 1974; Luukko 1954:354,422,434-437; Hedman 1969:107; Virrankoski 1973:341-348; Vahtola 1997a:73-78). By the 16th century the yearly salmon catches often exceeded 150 tons, and during the next century catches at least twice as big were common (Vahtola 1997b:121).

Cattle, through milk production, also played an important role in the region. This key secondary product was generally processed into butter, which was easily stored (Virrankoski 1973:235-243; Vahtola 1997b:127-129; Puputti 2009:25; Bläuer 2015:54). Hunting, for both fur and meat, was also a common practice (Luukko 1954:380-381,396398; Virrankoski 1973:270-276; Regnard 1982:24,97-103; Vahtola 1997b:127). The surplus of fish, butter, fur, and even forest berries was traded at the Kemi marketplace, attracting people from as far as southern Sweden (Hedman 1969:166; Virrankoski 1973:382-386; Regnard 1982:16,104; Vahtola 1997b:131-136). The parishioners essentially provided for the local clergy. Considering the aforementioned benefits a vicar received, Kemi was a rather desirable post, despite its remote location and subarctic climate (Hedman 1969:89).

\section{Biological Evidence Indicates High Status}

Although high status and wealth do not always go hand in hand, this seemed to be the case with Vicar Rungius. His noteworthy body size could be considered proof of his wealth, which would have allowed him to consume ample nutrition even during difficult times in the Kemi region, such as the early 17 th century (Vahtola 1997b:119). Nutrition affects such features as adult stature and body composition, since being able to consume an adequate if not profuse diet does support growth. Rich diets, however, can also cause certain ailments and conditions that have been clinically connected to such higher living standards. Nevertheless, it is likely that the ability to purchase food items alone would not have determined what a parish vicar was expected to consume, as the selection of socially acceptable and suitable dishes was probably also a reflection of his rank and status (Counihan 1999:7-10; Scholliers 2001).

The robust physical appearance of the mummy, as well as the results of the computed tomography conducted in 2011, do indeed testify to the generous nature of his diet. At an estimated reconstructed height of $177 \mathrm{~cm}$ (5.8 ft.), Vicar Rungius was rather tall compared to his common contemporaries (S. Niinimäki et al. 2011; Väre, S. Niinimäki et al. 2011; Väre, Junno et al. 2016; Väre 2017:91). In several Finnish osteoarcheological samples dating approximately from the 15 th to 19th centuries, the stature of the average man was between $161.8 \mathrm{~cm}$ (5.31 ft.) and $168.5 \mathrm{~cm}(5.53 \mathrm{ft}$.) (Maijanen 2006; Kortelainen et al. 2011; Salo 2016:59,90,110). Even as a child, Rungius's diet was likely sufficient, as nutritional deficiencies during childhood frequently lead to shorter adult statures (Eveleth and Tanner 1990:222-223; Malina et al. 2004:511-512; Väre, Junno et al. 2016; Väre 2017:91). This is also culturally consistent with his background as a member of a clergyman's family (Hyötyniemi 1953; Hedman 1969:90).

Nevertheless, in comparison with other individuals with high standards of living, his height would not have been a striking feature (Väre, Junno et al. 2016; Väre 2017:91). A study of remains of 18th-century inhabitants of a central European monastery (who would also have enjoyed high rank and status) found that they had 
an osteologically estimated mean stature of ca. $171 \mathrm{~cm}$ (5.61 ft.), while their local contemporaries averaged 162-165 cm (5.31-5.41 ft.) (Nerlich et al. 2015). In contrast, a typical, well-nourished Finnish man today has an average height of $180.7 \mathrm{~cm}(5.93 \mathrm{ft}$.) (Saari et al. 2011).

In addition to being tall, he was likely rather corpulent. According to his skeletal frame size (Ruff et al. 2005), he would have weighed approximately $75 \mathrm{~kg}$ (165.35 lb.). This estimation method, however, is incapable of determining the weight associated with soft tissues. It is also an underestimation, as the skeletal frame size that yielded the estimation of $75 \mathrm{~kg}$ only reveals the ideal body size for that particular bone structure. The method is incapable of taking into account the amount of muscle or fat tissues. The mummy's remaining left forearm, which would have rested across the abdomen at the time of burial, has been preserved in its original position prior to stomach deflation as a result of postmortem decomposition. As such, this "hanging" arm now provides an indication of the vicar's rather well-rounded abdomen. This argues that he was likely overweight, consuming a rather plentiful diet during his lifetime (Väre, Junno et al. 2016; Väre 2017:91-92).

While this appearance may to some extent be attributed to the accumulation and subsequent release of decomposition gases, the general conclusion that Vicar Rungius was overweight is also born out in the CT-scan data (Väre, Junno et al. 2016; Väre 2017:94-95). The strongest argument for such body composition and consumption of voluminous diet was a manifestation of diffuse idiopathic skeletal hyperostosis (DISH) in his thoracic spine (Fig. 3). There was even some extra bone formation in the heel bones and pelvis, presumably related to the condition. DISH is mostly an asymptomatic condition often only coincidentally revealed in radiological examinations. It is, however, most commonly encountered in elderly men exhibiting signs of metabolic disturbances, such as obesity and type 2 diabetes, indicating not only abundant diets, but perhaps a sedentary lifestyle also (Forestier and RotésQuerol 1950; Julkunen et al. 1971; Resnick and Niwayama 1976; Denko et al. 1994; Kiss et al. 2002; Musa et al. 2006; Manaster et al. 2013:272). What is more, DISH is a pathological condition in the skeletons of medieval and early modern clergy and upper-class individuals who typically enjoyed generous protein- and fat-rich diets and did not normally participate in physically laborious daily tasks (Waldron 1985, 2009:75-76; Janssen and Maat 1999; Rogers and Waldron 2001; Jankauskas 2003; Verlaan et al. 2007; Fornaciari et al. 2009; Giuffra et al. 2010; Núñez, Väre et al. 2013).

Even the stable-isotope analyses conducted on the vicar's nail keratin indicated a strong dietary input of animal protein that was probably at least partially derived from aquatic environments. This was indicated by his elevated nitrogen value $(\delta 15 \mathrm{~N} 14.6 \%$ ) (Väre 2017:72). Suitable candidates for the protein source would be top maritime hunters, such as seals and salmon, both very high in food chains (Schoeninger and DeNiro 1984; Schulting 1998), and/or the meat of young animals still being nursed. The nitrogen value is, indeed, enriched with every upward step in the food chain (Minagawa and Wada 1984). This also pertains to the effect of nursing, as the offspring is elevated to the next trophic level in comparison to the nursing mother (Fogel et al. 1989; Katzenberg et al. 1996; Schurr 1997; Herring et al. 1998). In early modern northern Finland, cows were kept for milk until they were old, but bulls could be slaughtered for meat at an earlier age-

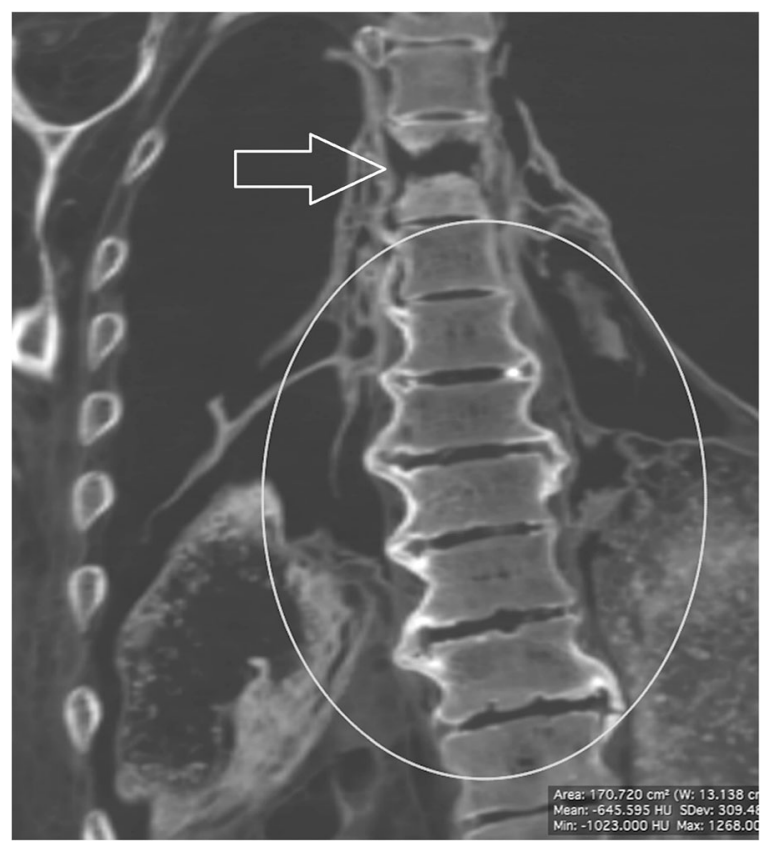

Fig. 3 Computed tomography revealed that Rungius suffered from DISH, which is a condition fusing vertebrae together (circled). It often correlates with high living standards, men, and aging. Judging by the other lesion in his upper thoracic spine (indicated by an arrow), he also may have suffered from tuberculosis. (Reconstructed CT image by J. Niinimäki, 2011.) 
according to archaeological analyses - typically at the age of 7-24 months (Virrankoski 1973:239; Puputti 2009:25-27). More expensive meat from the youngest nursed calves was probably not common, but likely still obtainable by the wealthy head of the parish. Additionally, the organs, meat, and blood of young animals and even the mother's milk was sometimes used as medicine against certain diseases and conditions (Hausen 1920; Olai 2008:29,69).

There are, nevertheless, many problems in interpreting isolated isotope values, particularly as nail keratin samples offer only a very temporally restricted overview of the diet of the subject. For instance, in a dead individual nail keratin is capable of revealing the diet during a maximum of one-year prior to death. Death, on the other hand, is often associated with pathological conditions, some of which are known to alter the isotopic composition of tissues or simply affect the values due to their link to diet. If the cause of death remains unknown, the values may be especially misleading. One example of a condition that seems to affect the isotope values is DISH, which has been linked to both elevated nitrogen values and heavy, protein-rich diets (Müldner and Richards 2007; Spencer 2008:243). To make matters even more complex, malnutrition is also known to elevate nitrogen values (Hatch et al. 2006; Mekota et al. 2006). As the vicar may have been sick during his last months, his high nitrogen value may also reflect his failing health and appetite (Väre 2017:97).

However, the protein-/fat-rich diet indicated by the isotopes is supported by his dental health. His dentition does not provide any indication of an abundance of carbohydrate-rich foodstuffs, and it was in relatively good condition considering the age of the septuagenarian vicar. Only three major cavities were observed, and three teeth were missing, of which one may have been lost postmortem. This perhaps implies lower proportional intake of carbohydrates as opposed to fats and proteins (Navia 1994; Väre, Junno et al. 2016; Väre 2017:72,92; Väre, Vilkama et al. 2017).

These conclusions about his diet are consistent with diet in northern Finland at the time. In early modern northern Finnish towns on the coast of the Gulf of Bothnia, diet was based mainly on fishing, hunting, and animal husbandry (Luukko 1954:381-479; Virrankoski 1973:179-348; Regnard 1982:28,97104,107; Salmi 2011; Vilkama et al. 2016). Kemi parish experienced no shortage of fish, although by the turn of the 17 th century tax reports indicate that salmon catches were smaller than usual (Vahtola 1997b:121). The exploitation of aquatic environments was not limited to fishing either, and included waterfowl and even seals as sources of nutrition (Luukko 1954:398-399,437-441; Virrankoski 1973:276-278; Regnard 1982:28-29; Kvist 1988; Ylimaunu 2000:332; Puputti 2009:50).

In contrast with the aquatic abundance, during Rungius's tenure in the north the cultivation of crops was still in its infancy, and the meadowlands revealed by the isostatic rebound were mainly utilized for animal husbandry (Vahtola 1997b:128-131). Carbohydratecontaining berries, honey, bread, and porridges, and even wine, beer, and spirits were included in a normal diet, but sugar was not commonly used, even by the elite (Virkkunen 1919:374-375; Mäntylä 1971:511; Outhier 1975:116; Magnus 1976:286-300; Regnard 1982:16,111-112; Mintz 1993; Tranberg 2011; Vilkama et al. 2016).

A collapse lesion impacting Rungius's thoracic spine argues that he might have been physically inactive at some point of his life. The lesion was speculated to represent an aftereffect of spondylodiscitis that likely resulted from a tuberculosis infection, but, despite its aetiology, it had certainly inflicted pain, at least at some point during the vicar's life (Väre, J. Niinimäki et al. 2016; Väre 2017:87). Sometimes similar lesions can put pressure on the spinal cord and lead to neurological symptoms, such as weakness in the limbs and even paraplegia. Respiratory problems may also occur in relation to kyphosis and shortening of the trunk that result from the collapse lesion (Darouiche et al. 1992; Akalan and Özgen 2000; Aufderheide and RodriquezMartin 2011:123). Considering this, the vicar may have been in constant, severe pain and his movements neurologically or morphologically impaired, which could have rendered him nearly immobile. Overall, however, avoiding physical labor would have been much easier for a man of his occupation, wealth, and status than for his lower-status counterparts. Instead of being forced to earn his living performing strenuous tasks, he could rely on his parishioners' hard work in exchange for his religious services (Virrankoski 1973:681-683; Regnard 1982:104).

Dietary choices impact not only body proportions, but also health. While too rich a diet may be unhealthy, sufficient nutrition is a requirement for maintaining good health. One indication of such nutrition and rather stable living conditions is longevity, while poor living conditions generally lead to shortened lifespan. Vicar 
Rungius, who apparently died in his late 60 s or early 70 s, enjoyed a longer lifespan in contrast to his poorer contemporary parishioners. While the mean life expectancy in the Swedish kingdom in the mid-18th century was about 34 years (Gurven and Kaplan 2007:327,332; Väre, Junno et al. 2016), during the century between 1698 and 1797 (the earliest existing data for Kemi) the mean age at death for males was less than 20 years (Väre 2017:60), although this reflects high infant mortality. In fact, if people lived past childhood, their lifespans were typically more than 50 years (Väre 2017:61).

\section{Appropriate for a Vicar: Funerary Attire}

Because Rungius was lifted from one coffin to another several times, any probable interior textiles have decayed. The only possible evidence for the bedding inside the coffin is a barbule of a bird feather or down identified along with the stocking fibers (Fig. 4). It is possible that the mattress or pillow were down filled, something which has been noted in a number of Ostrobothnian burials from Oulu and Hailuoto. It is also possible that the down stuck to the stocking while it was still in use or was brought into the burial by rodents that visited the burial (Väre, Lipkin et al. 2016).

Rungius has various textile fragments on the skin of his feet, chest, and arms. Generally, the textiles are in relatively good condition, both visually and on the microscopic scale. Possible textiles on his back or situated beneath him cannot be studied due to the fragile state of the human remains. However, several features suggest that he was buried in higher-end attire.

Preliminary fiber analysis showed that all fabric samples observed on the vicar were made of plant fibers. However, observation of the surface characteristics is not adequate to distinguish the bast-fiber species (flax, hemp, and nettle) from one another (Bergfjord and Holst 2010). For this reason, the fiber samples were analyzed with a combination of microscopic surface-analysis methods, a modified Herzog test, and cross-sectional observation by transmitted-light microscope Leica DM4500 (Suomela et al. 2017).

Rungius was dressed in knit, knee-length stockings made of flax (Lipkin et al. 2015), which left depressions of reverse stockinette stitches from knitted fabric on his skin in the areas where the stockings have decayed (Fig. 5). The stockings have 40 stockinette stiches $/ 10 \mathrm{~cm}$, which means that they were of very fine quality and made of thin thread (ca. $0.6 \mathrm{~mm}$ thick). During the early 17 th century linen stockings were more expensive than wool stockings. In southwestern Finland, both wool and linen stockings were hand knitted by women in such massive quantities that their surplus could be sold in Stockholm and Germany. These activities displayed standardization characteristics that would qualify as professional production (Pylkkänen 1970:377-378). Rungius's stockings are clearly of a quality made by an experienced knitter, but it remains unclear whether the stockings were made in northern Finland or in southwestern Finland where Rungius was born. It may be assumed that, during Rungius's time, linen stockings were considered superior by those who could afford them, although noblemen used them on a daily basis and under silk stockings during the summer season. At the time, noblemen owned several pairs of linen stockings for daily use (Pylkkänen 1970:378). It is possible that one pair of Rungius's own stockings was put on his feet for burial. Silk knit stockings, worn before their deposition in the burial, have been found in other 17 th- to early 18 th-century burials in northern Finland (for instance, in Oulu and Hailuoto). Silk preserves due to its hygroscopic nature, and lack of bast-fiber stockings may be just a matter of preservation (Lipkin, Ruhl, Vajanto et al., this issue).

In the early 17th century, gentlemen decorated their feet with sock garters tied into large bows. These were usually made of bright-colored silk and with metallic lace or fringes on the ends (Pylkkänen 1970:378-379, figures 118,119$)$. Today, Rungius does not have such garters, but both of his legs have depressions below his knees at the point where garters usually tightened the stockings, and it is possible that he was originally wearing them. If they had been made of silk, they could have been removed by later generations. This is possible, as silk would have preserved smooth and colorful for decades or centuries, and, as such, the garters would have been precious items. Nevertheless, Rungius's garters may also have been crafted from linen and decayed over the centuries along with his stockings.

Rungius was buried in funerary attire made of different kinds of high-quality fabrics. On the skin of his upper body, fragmentary traces of nettle fabric were found. These fine-quality pieces may belong to Rungius's funerary shirt. Two other fragments of nettle and cotton fabrics were found on the right thigh (Figs. 6, 7). Although the textile remains are fragmentary and small, the quality of their weaving and 
Fig. 4 The barbule of a bird feather was found among the fibers of the stockings. The feather is indicated by an arrow. (Photo by K. Vajanto, 2017.)
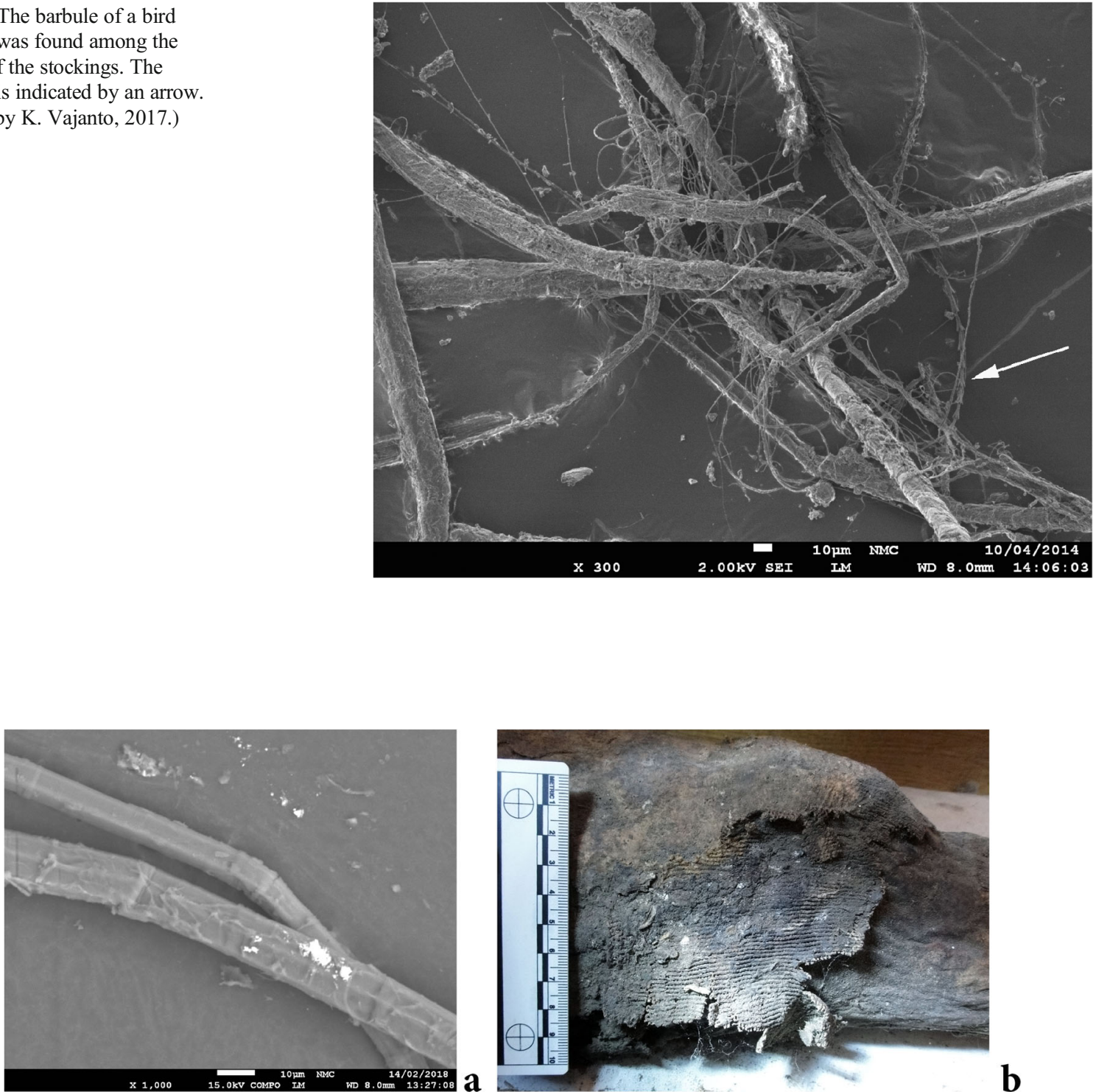

b

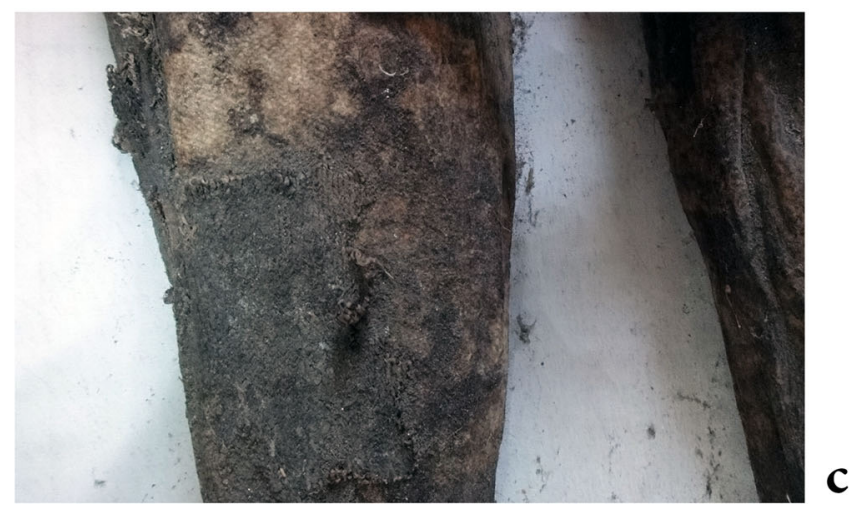

Fig. 5 Flax fibers from the stocking of Vicar Rungius, with some iron particles (bright white) on the fiber surface $(a)$, remains of the stocking on the right side of the knee $(b)$, and stockinette-stitch impressions on Rungius's skin (c). (Photos by K. Vajanto and S. Lipkin, 2014.) 
Fig. 6 On the right tight of Rungius, two fragments of finequality nettle and cotton textiles were found. (Photo by S. Lipkin, 2014.)

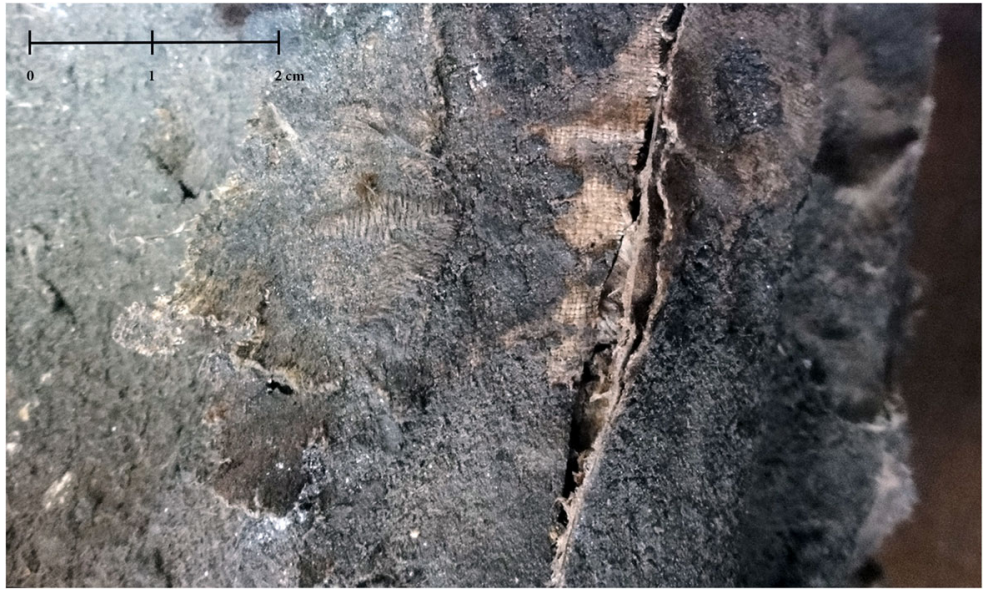

knitting, generally employing thin threads (varying between 0.2 and $0.4 \mathrm{~mm}$ ) and a high thread count (varying between 20 and 30 threads/cm) bears witness to his high status and the availability of finequality textiles for his burial. It is possible that Rungius was buried wearing one of his priestly shirts, and his body, arms, and legs were tied and covered with fabrics in a manner similar to the burial of Bishop Peder Winstrup, from Lund in southern Sweden, approximately 50 years later (buried in 1680). Bishop Winstrup was wrapped, tied, and covered with a large variety of bast-fiber fabrics, ranging from coarse to extremely fine quality (from 10 to 14 threads $/ \mathrm{cm}$ to 37 to 43 threads $/ \mathrm{cm}$ ). His priestly shirt, with a black silk bow and a large collar, was placed on him, and only his hands were inside the shirt. Winstrup's feet did not have real socks, but were wrapped with textile strips. In addition to the shirt, Bishop Winstrup's only "real" clothes were a black silk corduroy cap, a black short cloak around the shoulders, and leather gloves (Karsten and Manhag 2017:102-104).

Indeed, Winstrup's burial clothing is similar to other examples of burial clothes that were constructed of reused fabrics from unfashionable clothes or other old textiles. In southwestern Turku during the 17th and 18th centuries, preserved silk burial clothes were not real clothes, as they had open backs. During the 17th century such clothes were sewn to resemble real clothes, but at the turn of the 18th century they were increasingly attached to the coffin interior with pins. Burial clothes from 17th-century Turku studied by Pylkkänen (1953:25-29) were all silk, which may be a matter of burial custom or, more likely, preservation. During the 18 th century the number of preserved plant-fiber fabrics increased as well. At Oulu Cathedral (about $100 \mathrm{~km}$ south of Keminmaa), most of the preserved textiles were made of wool and silk, whereas only a few bast-fiber
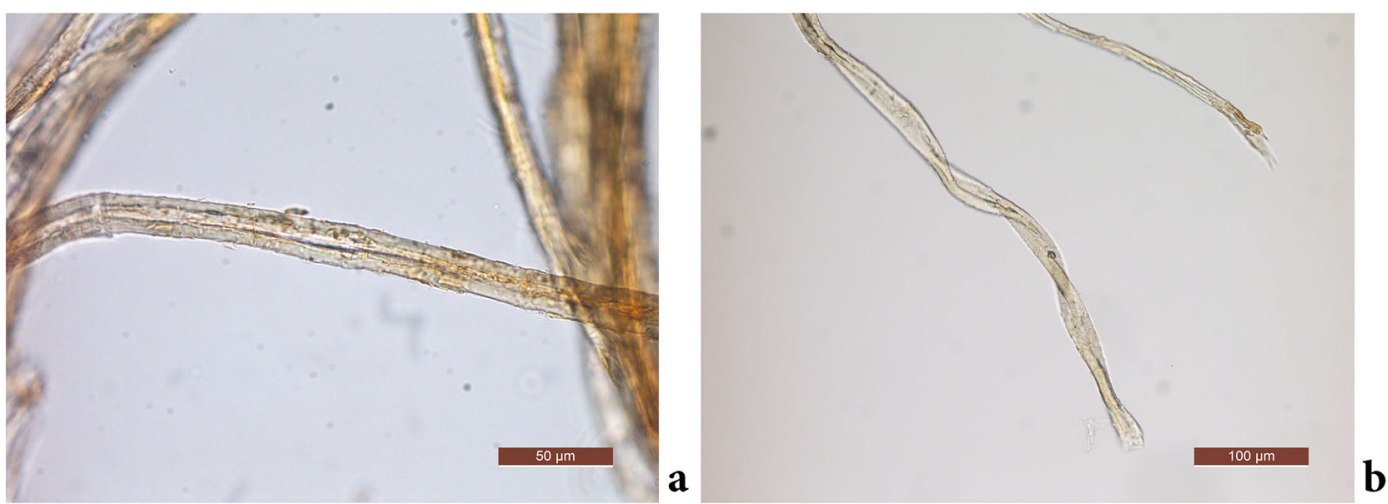

Fig. 7 Nettle and cotton fibers of the textiles on the leg. (Photo by J. Suomela, 2017.) 
Fig. 8 Painting on the ceiling of St. Michael's Church in Keminmaa depicting priests wearing simarres. (Photo by $\mathrm{T}$. Kallio-Seppä, 2018.)

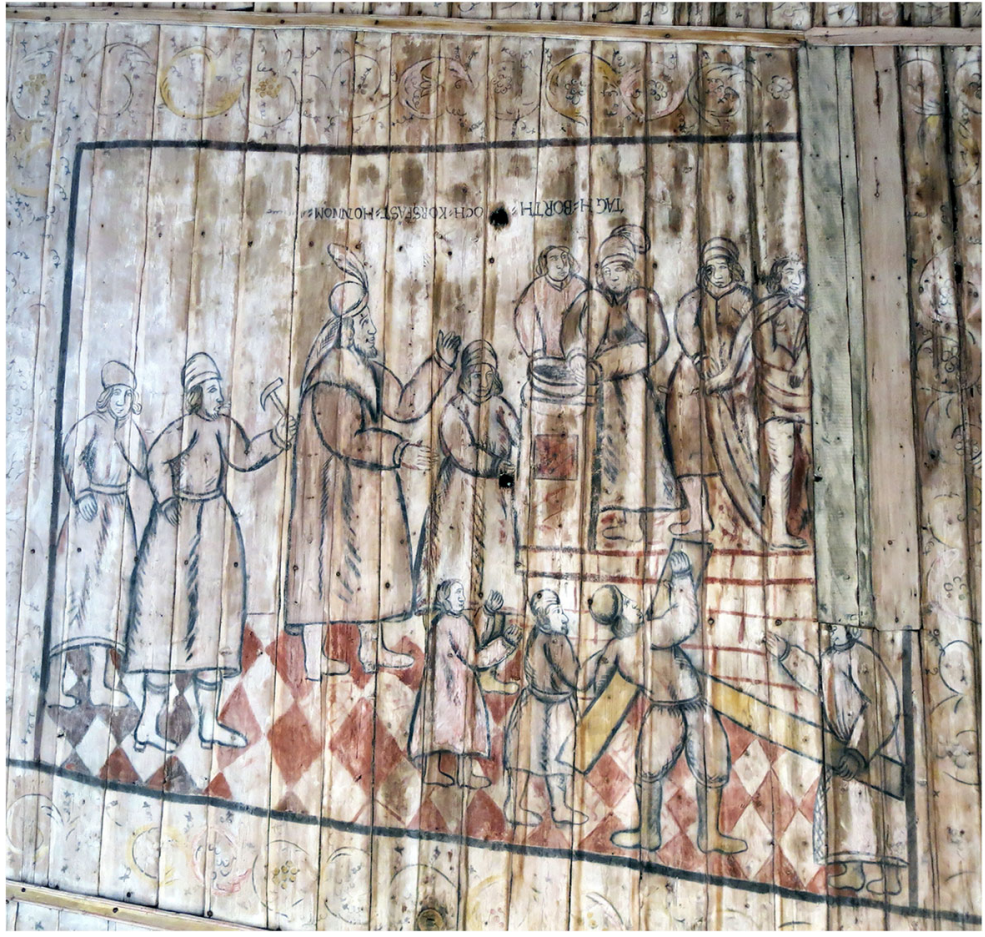

fabrics have been identified (Lipkin and Kuokkanen 2014), although these materials have not yet been identified by species. The material analysis from this research does not correspond with Pylkkänen's findings regarding the material choices in funeral attire from the same period in Turku. Further research on Rungius's funeral clothing and plant-fiber funeral clothing from the region is required.

The use of nettle and cotton fibers in this context is unique, likely due to recent advances in the analysis of archaeological textile fibers enabling increasingly precise identifications. The history of both nettle and cotton use in Finland is currently understudied, making it difficult to determine the frequency of nettle in comparison to the use of linen, or the prevalence of cotton in comparison to other fiber materials. During the early 17 th century, Finland produced its own linen (and presumably also nettle), but fine bast-fiber, plain-woven fabrics were also imported from Holland, Lübeck, Pomerania, and Denmark (Pylkkänen 1955:68-69). During the 17 th century good-quality bast-fiber undergarments were relatively valuable and appear to have been an indication of wealth and high class. As such, they appear in a number of probate inventories (Lempiäinen 2016:63).
The cotton fabric on Rungius's legs was most likely imported from India, which was the main producer of cotton fabrics during the early 17th century. Cotton fabrics were more expensive than linen and nettle textiles, and in Finland cotton was a rare material, typically used only for small accessories, such as handkerchiefs (Pylkkänen 1970:82, 1982:58-59,63). Potentially, the fabric on Rungius's legs was originally much larger, which would testify to his luxurious burial attire. Based on the high-quality textiles in Rungius's burial, it may be assumed that his wealth was sufficient so that his surviving family members could afford to include such items in his burial instead of saving them for future use. It may also be assumed that Rungius's sumptuous funerary attire underlined his status while parishioners were saying farewell during the wake period.

Unlike Bishop Winstrup, Rungius does not currently wear a cap, gloves, or cloak, although it is possible that these items were removed when he was shifted from one coffin to another. The remains are also missing the scalp, possibly due to the same activities. As priests were supposed to dress in a certain manner, it is likely that, if not buried with priestly garments, Rungius at least owned them during his lifetime. A long, loose fur-trimmed black gown, known as a simarre (or cymar), was part of priests' and scholars' official clothing from the 16th century until 
the late 17th century. Such simarres were tied with belts and are depicted on the Finnish church ceiling paintings dating from this period, including those at Keminmaa's church (painted in 1650) (Fig. 8), where Rungius is buried (Pylkkänen 1956:115).

\section{Conclusions}

Thus far, our studies of Vicar Rungius tell a story of the son of an affluent, early modern clergy family. Following in his family's footsteps, he made his career serving as a clergyman, and eventually advanced to the rank of vicar, as his father and father-in-law had done. In this role, he was essentially the ecclesiastical ruler of his own, quite independently operating, geographically vast, northern parish that was built upon rich natural resources. He was, by all accounts, a rather wealthy man. It seems that, despite the often harsh and cruel environmental conditions in the subarctic, the local people were able to exploit the available resources to maintain their vicars in a quite satisfactory manner. Vicar Rungius's life was shaped by both rather high social status and rank, and the accompanying wealth that ensured him a prestigious and enjoyable social position.

Even though every evidence suggests that he experienced a high-status life, his status did not remain unchanged. Vicar Rungius was a rather tall man, which would imply that his childhood nutrition had been sufficient. However, during his life he experienced changes in his status while entering adulthood, during his studies, on becoming a priest, and, finally, for the last 15 years of his life while holding the office of vicar. In his remains can be seen, in particular, the effects of his status during his adulthood and, specifically, in his old age and at the time of his death. The presence of certain indications of diseases that are clinically related to ample diets implies that he probably consumed a rather excessive diet, even in his later years. According to his stable-isotope values - although particularly isolated and difficult to interpret-his diet was likely rich in animal-based proteins. This is corroborated not only by historical evidence regarding the local contemporaneous diet, but also by the findings regarding his dental health. The food that he ate was likely largely derived from the local bodies of water. He perhaps also consumed meat of young animals, which may be considered as either a luxury or as a medication against his various ailments.
His burial place was, in accordance with his rank as the parish vicar, not only located under his church, but prestigiously placed beneath the chancel. Although his original coffin and coffin linen are now lost, the fragmented textile remains on his skin suggest that he was buried in elaborate funerary attire. The qualities of the four different nettle and cotton textiles preserved are fine, and on his feet Rungius wears linen stockings knit with fine thread. All preserved textile fragments on his skin indicate luxury commodities and sumptuous products of his era. The wide range of sources, artifacts, and lines of evidence, ranging from burial data to paleopathological diagnosis, paints a robust, complex picture of the life of a high-status, early modern vicar.

Acknowledgments: We are grateful to Jaakko Niinimäki for performing the computed-tomography imaging of the Vicar Rungius in 2011. Without his effort, the vicar would have kept most of his secrets. We also thank Markku Niskanen, JuhoAntti Junno, Milton Núñez, and Sirpa Niinimäki, who were involved in the arrangements of the imaging. We also are grateful to Erika Ruhl for her assistance in proofreading the article. The research was a part of the Church, Space and Memory Project funded by the Emil Aaltonen Foundation, Finland, and led by Titta Kallio-Seppä and Sanna Lipkin's academy research-fellow project: Daily and Afterlife of Children in Post-Medieval Finland (1500-1900)—New Perspectives in Identifying Childhood in the Past.

Funding Open access funding provided by University of Oulu including Oulu University Hospital.

Open Access This article is licensed under a Creative Commons Attribution 4.0 International License, which permits use, sharing, adaptation, distribution and reproduction in any medium or format, as long as you give appropriate credit to the original author(s) and the source, provide a link to the Creative Commons licence, and indicate if changes were made. The images or other third party material in this article are included in the article's Creative Commons licence, unless indicated otherwise in a credit line to the material. If material is not included in the article's Creative Commons licence and your intended use is not permitted by statutory regulation or exceeds the permitted use, you will need to obtain permission directly from the copyright holder. To view a copy of this licence, visit http://creativecommons.org/licenses/by/4.0/.

\section{References}

Akalan, Nejat, and Tuncalp Özgen

2000 Infection as a Cause of Spinal Cord Compression: A Review of 36 Spinal Epidural Abscess Cases. Acta Neurochirurgica 142(1):17-23. 
Aufderheide, Arthur C., and Conrado Rodriguez-Martin 2011 The Cambridge Encyclopaedia of Human Paleopathology. Cambridge University Press, Cambridge, UK.

Babić, Staša

2005 Status Identity and Archaeology. In The Archaeology of Identity. Approaches to Gender, Age, Status, Ethnicity and Religion, Margarita Díaz-Andreu, Sam Lucy, Staša Babić, and David N. Edwards, editors, pp. 6785. Routledge, New York, NY.

Bergfjord, Christian, and Bodil Holst

2010 A Procedure for Identifying Textile Bast Fibres Using Microscopy: Flax, Nettle/Ramie, Hemp and Jute. Ultramicroscopy 110(9):1192-1197.

Bläuer, Auli

2015 Voita, Villaa ja Vetoeläimiä. Karjan ja Karjanhoidon Varhainen Historia Suomessa (Butter, Wool and Draught Animals. Early History of Cattle and Cattle Husbandry in Finland). Turun yliopisto, Karhunhammas 17. Turku, Finland.

Borg, Felix

1944 Vanha Kirkko ja Kirkkoherra (Old church and vicar). Helsingin sanomat 22 June:4. Helsinki, Finland.

Cajanus, Kaarlo Ilmari

1927 Piirteitä Kemin Maaseurakunnan Kirkkojen Historiasta (Features of Kemi parish church history). Tekijä, Tornio, Finland.

Calamnius, Johan W.

1868 Muinais-tiedustuksia Pohjanperiltä (Notes concerning ancient times in Ostrobothnia). Suomi: Kirjoituksia Isän-maallisista Aineista 2(7):191-267.

Counihan, Carole M.

1999 The Anthropology of Food and Body. Gender, Meaning, and Power. Routledge, New York, NY.

Darouiche, Rabih O., Richard J. Hamill, Stephen B. Greenberg,

Susan W. Weathers, and Daniel M. Musher

1992 Bacterial Spinal Epidural Abscess: Review of 43 Cases and Literature Survey. Medicine 71(6):369-385.

Denko, Charles W., Betty Boja, and Roland W. Moskowitz

1994 Growth Promoting Peptides in Osteoarthritis and Diffuse Idiopathic Skeletal HyperostosisInsulin, Insulin-Like Growth Factor-I, Growth Hormone. Journal of Rheumatology 21(9):1725-1730.

Eveleth, Phyllis B., and James M. Tanner

1990 Worldwide Variation in Human Growth. Cambridge University Press, UK.

Fogel, Marilyn L., Noreen Tuross, and D. Owsley

1989 Nitrogen Isotope Tracers of Human Lactation in Modern and Archaeological Populations. Annual Report of the Director, Geophysical Laboratory, Carnegie Institution of Washington, 1988-1989, pp. 111-116. Carnegie Institution of Washington, Washington, DC.
Forestier, Jacques, and Jaume Rotés-Querol

1950 Senile Ankylosing Hyperostosis of the Spine. Annals of the Rheumatic Diseases 9(4):321-330.

Fornaciari, Gino, Valentina Giuffra, Sara Giusiani, Antonio Fornaciari, Natale Villari, and Angelica Vitiello

2009 The 'Gout' of the Medici, Grand Dukes of Florence: A Palaeopathological Study. Rheumatology 48(4):375-377.

Giuffra, Valentina, Sara Giusiani, Antonio Fornaciari, Natale Villari, Angelica Vitiello, and Gino Fornaciari

2010 Diffuse Idiopathic Skeletal Hyperostosis in the Medici, Grand Dukes of Florence (XVI Century). European Spine Journal 19(S2):103107.

Gurven, Michael, and Hillard Kaplan

2007 Longevity among Hunter-Gatherers: A CrossCultural Examination. Population and Development Review 33(2):321-365.

Hatch, Kent A., Morgan A. Crawford, Amanda W. Kunz, Steven R. Thomsen, Dennis L. Eggett, Stephen T. Nelson, and Beverly L. Roeder

2006 An Objective Means of Diagnosing Anorexia Nervosa and Bulimia Nervosa Using 15N/14N and $13 \mathrm{C} / 12 \mathrm{C}$ Ratios in Hair. Rapid Communications in Mass Spectrometry 20(22):3367-3373.

Hausen, R.

1920 När "mastermannen" förrättade sitt ämbete (When the "masterman" performed his profession). Åland 6:85-92.

Hedman, Ossi

1969 Kemin Kaupungin Historia I. Katsaus Kemin Seudun ja Kemin Lapin Varhaisempiin Vaiheisiin (History of Kemi Town I. Overview of the earliest periods of the Kemi region and Kemi Lapland). Kemin kaupunki, Tampere, Finland.

Herring, D. Ann, Shelley R. Saunders, and M. Anne Katzenberg 1998 Investigating the Weaning Process in Past Populations. American Journal of Physical Anthropology 105(4):425-439.

Hiekkanen, Markus

2014 Suomen Keskiajan Kivikirkot (Medieval stone churches in Finland). Suomalaisen Kirjallisuuden Seura, Helsinki, Finland.

Huurre, Irene

1983 Vainajiin Osataan Maalla Suhtautua Luontevasti. Keminmaalaiset: Rungius-kohu Hurskastelua (In the countryside people react to death naturally. The people of Keminmaa: The Rungius sensation and piety). Helsingin Sanomat 31 January:12. Helsinki, Finland.

Hyötyniemi, Jaakko Eeli

1953 Muinainen Suur-Kemi ja sen Papiston Sivistysmerkitys (Ancient Great-Kemi and its priestly cultural significance). Jatuli 4:32-43.

Jankauskas, Rimantas

2003 The Incidence of Diffuse Idiopathic Skeletal Hyperostosis and Social Status Correlation in Lithuanian Skeletal Materials. International Journal of Osteoarchaeology 13(5):289-293. 
Janssen, H. A. M., and H. J. R. Maat

1999 Canons Buried in the "Stiftskapel" of the Saint Servaas Basilica at Maastricht, A.D. 10701521. A Paleopathological Study. Leiden University Medical Center, Barge's Anthropologica 5. Leiden, the Netherlands.

Julkunen, Heljo, Olli P. Heinonen, and Kalevi Pyörälä

1971 Hyperostosis of the Spine in an Adult Population. Annals of the Rheumatic Diseases 30(6):605-612.

Kallinen, Maija

1990 Legendoja ja Käsityksiä Rungiuksesta Kansan Suussa ja Politiikan Välineenä (Legends and understandings of Rungius in the mouth of the people and as an instrument of politics). Jatuli 21:124-136.

Karsten, Per, and Andreas Manhag

2017 Peder Winstrup - Historier kring en 1600talsmumie (Peder Winstrup - History surrounding a 1600 s mummy). Lunds universitet, Historiska museet, Lund, Sweden.

Katzenberg, M. Anne, D. Ann Herring, and Shelley R. Saunders

1996 Weaning and Infant Mortality: Evaluating the Skeletal Evidence. American Journal of Physical Anthropology 101(S23):177-199.

Kiss, Csaba, Melinda Szilági, A. Paksy, and G. Poor

2002 Risk Factors for Diffuse Idiopathic Skeletal Hyperostosis: A Case-Control Study. Rheumatology 41(1):27-30.

Knihtilä, Jouni

1982 Keminmaan Muumio Kiinnostaa ja Askarruttaa (The mummy from Keminmaa is a subject of interest and wonder). Kaleva 2 August:6. Oulu, Finland.

Kortelainen, Tiina, Mia Holappa, and Sirpa Niinimäki

2011 Paino- ja Pituusarvioita (Estimations of weight and stature). In Iin Haminan kirkko ja hautausmaa. Arkeologisia tutkimuksia, Titta Kallio-Seppä, Janne Ikäheimo, and Kirsi Paavola, editors, pp. 127-133. University of Oulu, Department of Archaeology, Oulu, Finland.

Kuokkanen, Tiina

2016 Vaatetuksen luokka ja sukupuoli 1600-1800-

lukujen Oulussa. Historiallisen Ajan Arkeologian Näkökulma. (Clothing by class and gender in 17th- to 19th-century Oulu. An historical archaeological perspective). Acta Universitatis Ouluensis B Humaniora 137. Oulu, Finland.

Kvist, Roger 1988

Sälfăngstsätten i Österbotten, Västerbotten och Norrbotten 1551-1570 (Sealing methods in Ostrobothnia, Västerbotten and Norrbotten 1551-1570). Oknytt 9(1\&2):4-14. Johan Nordlander sällskapet <http://www.johannordlan dersallskapet.se/oknytt/1988 1-2.pdf>. Accessed 24 August 2020.

Lempiäinen, Pentti

1990 Hautausmaaperinteen Rikkaus (Richness of cemetry traditions). In Viimeiset leposijamme.
Hautausmaat ja Hautamuistomerkit, Pentti Lempiäinen and Brita Nickels, editors, pp. 620. Sley kirjat, Imatra, Finland.

Lempiäinen, Pia

2016 Vaatteet, Muoti ja Asema: Oululaisten Pukeutuminen 1600-luvulla (Clothes, fashion and rank: Clothing of the citizens of Oulu during the 17th century). Master's thesis, Department of History, University of Helsinki, Helsinki, Finland.

Lipkin, Sanna, and Tiina Kuokkanen

2014 Man Buried in His Everyday Clothes-Attire and Social Status in Early Modern Oulu. In Focus on Archaeological Textiles: Multidisclipinary Approaches, Sanna Lipkin and Krista Vajanto, editors, pp. 40-53. Monographs of the Archaeological Society of Finland 3. Oulu, Finland. Suomen Arkeologinen Seura <http://www.sarks.fi/masf/masf 3/MASF3_03_Lipkin_Kuokkanen.pdf\$. Accessed $\overline{2} 4$ August 2020 .

Lipkin, Sanna, Krista Vajanto, Titta Kallio-Seppä, Tiina Kuokkanen, Sirpa Niinimäki, Tiina Väre, and Martin van Bommel 2015 Funeral Dress and Textiles in 17th- and 19thCentury Burials in Ostrobothnia, Finland. In Aspects of the Design, Production and Use of Textiles and Clothing from the Bronze Age to the Early Modern Era. NESAT XII. The North European Symposium of Archaeological Textiles 21st-24th May 2014 in Hallstatt, Austria, Karin Grömer and Frances Pritchard, editors, pp. 209-221. Archaeolingua, Budapest, Hungary.

Luukko, Armas

1954 Pohjois-Pohjanmaan ja Lapin historia II. Pohjois-Pohjanmaan ja Lapin keskiaika sekä 1500-luku (History of northern Ostrobothnia and Lapland II. The Middle Ages and the 16th century in northern Ostrobothnia and Lapland). Pohjois-Pohjanmaan Maakuntaliiton ja Lapin Maakuntaliiton yhteinen historiatoimikunta, Oulu, Finland.

Magnus, Olaus 1976

Olaus Magnus. Historia om de Nordiska Folken. Sjuttonde till Tjugoandra Boken (Olaus Magnus. History of the Nordic peoples. The seventeenth to the twenty-second book). Tofters tryckeri ab, Östervåla, Sweden.

Maijanen, Heli 2006

Stature Estimation for a 17th and 18th Century Oulu Population. In People, Material Culture and Environment in the North. Proceedings of the 22nd Nordic Archaeological Conference University of Oulu, 18-23 August 2004, VesaPekka Herva, editor, pp. 329-335. University of Oulu, Studia Humaniora Ouluensia 1. Oulu, Finland.

Malina, Robert, Claude Bouchard, and Oded Bar-Or 2004 Growth, Maturation, and Physical Activity. Human Kinetics, Inc., Champaign, IL.

Manaster, B. J., David A. May, and David G. Disler 
2013 Musculoskeletal Imaging: The Requisites, 4th edition. Elsevier Saunders, Philadelphia, PA.

Mäntylä, Ilkka

1971 Tornion Kaupungin Historia I, 1621-1809 (History of Tornio Town I, 1621-1809). Tornion kaupunki, Tornio, Finland.

Mekota, Anna-Maria, Gisela Grupe, Sandra Ufer, and Ulrich Cuntz 2006 Serial Analysis of Stable Nitrogen and Carbon Isotopes in Hair: Monitoring Starvation and Recovery Phases of Patients Suffering from Anorexia Nervosa. Rapid Communications in Mass Spectrometry 20(10):1604-1610.

Minagawa, Masao, and Eitaro Wada

1984 Stepwise Enrichment of $15 \mathrm{~N}$ along Food Chains: Further Evidence and the Relation between $\delta 15 \mathrm{~N}$ and Animal Age. Geochimica et Cosmochimica Acta 48(5):1135-1140.

Mintz, Sidney V.

1993 The Changing Role of Food in the Study of Consumption. In Consumption and the World of Goods, J. Brewer and R. Porter, editors, pp. 261-273. Routledge, London, UK.

Mrozowski, Stephen A.

2006 The Archaeology of Class in Urban America. Cambridge University Press, Cambridge, UK.

Müldner, Gundula, and Michael Richards

2007 Diet and Diversity at Later Medieval Fishergate: The Isotopic Evidence. American Journal of Physical Anthropology 134(2):162174.

Musa, A. K. M., Khwajah Nazimuddin, S. A. Huq, R. S. C. Sarker, and A. K. M. S. Ahmed

2006 Rheumatic Disorders and Bone Problems in Diabetes Mellitus. The Orion Medical Journal 23:344-346.

Navia, Jose M.

1994 Carbohydrates and Dental Health. American Journal of Clinical Nutrition 59(S3):719-727.

Nerlich, Andreas G., Alfred Riepertinger, Ralph Gillich, and Stephanie Panzer

2015 Paleopathology and Nutritional Analysis of a South German Monastery Population. BioMed Research International 4:1-9. Hindawi $<$ https://www.hindawi.com/journals/bmri/2015/ 486467/>. Accessed 3 September 2020.

Niinimäki, Sirpa, Tiina Heikkilä, Jaakko Niinimäki, Markku Niskanen, Milton Núñez, and Juho-Antti Junno

2011 Rungiuksen Muumion Osteoantropologinen

Tutkimus (Osteoanthropological research on Rungius's mummy). In Harmaata näkyvissä-Kirsti Paavolan juhlakirja, Janne Ikäheimo, Risto Nurmi, and Reija Satokangas, editors, pp. 265-274. University of Oulu, Oulu, Finland.

Núñez, Milton, Kirsti Paavola, and Elena García-Guixe

2008 Mummies in Northern Finland. In Mummies and Science, World Mummies Research, Proceedings of the VI World Congress on Mummy Studies. Teguise, Lanzarote, February 20th to 24th, 2007, Atoche Peña, C. Rodgues Martin, and M. Ángeles Ramírez
Rodríquez, editors, pp. 123-128. Academia Canaria de la Historia, Santa Cruz de Tenerife, Spain.

Núñez, Milton, Tiina Väre, Juho-Antti Junno, Jaakko Niinimäki, Sirpa Niinimäki, and Markku Niskanen

2013 DISH in Two Members of Finland's 17thCentury Upper Class. In Vetera corpora morbo afflicta. Actas del XI Congreso Nacional de Paleopathologia, A. Malgosa, A. Isidro, P. Ibáñez-Gimeno, and G. Prats-Muñoz, editors, pp. 477-488. Edición de la Universitat Autònoma de Barcelona, Barcelona, Spain.

Olai, Benedictus

2008 Een nyttigh läkere book. Benedictus Olain lääkärikirja vuodelta 1578 (A useful doctor's book. Benedictus Olai's medical book of 1578), Sakari Härö, translator. Suomen lääkäriliitto, Otava, Keuruu, Finland.

Oulun maakunta-arkisto (OMA)

1700-1716 Kirkon tulojen ja menojen tilit (The church's income and expenditure accounts), 9 October 1704. IIITI:2, Pääkirja, Kemin seurakunnan arkisto, Kemin seurakunta, Oulun maakuntaarkisto, Oulu, Finland. Digitaaliarkisto, Kansallisarkisto <http://digi.narc.fi/digi/view . ka?kuid=5856039>. Accessed 9 February 2016.

Oulun maakunta-arkisto (OMA)

1728 Hautaluettelo (List of graves). IAI:1, Hautausmaata- ja -kappelia koskevat asiakirjat, Kemin seurakunnan arkisto, Kemin seurakunta, Oulun maakunta-arkisto, Oulu, Finland. Digitaaliarkisto, Kansallisarkisto <http://diginarc .fi/digi/view.ka?kuid=37120262>. Accessed 31 August 2020.

Oulun maakunta-arkisto (OMA)

1862-1978 Piispantarkastuksenpöytäkirjat (Minutes of the bishop's visitations), 17 September 1892. Eb: 32, Oulun hiippakunnan tuomiokapitulin arkisto, Oulun maakunta-arkisto, Oulu, Finland.

Outhier, Réginald

1975 Matka Pohjan perille 1736-1737 (A trip to the far north 1736-1737), M. Itkonen-Kaila, translator. Otava, Helsinki, Finland.

Paavola, Kirsti

1998 Kepeät mullat. Kirjallisiin ja esineellisiin lähteisiin perustuva tutkimus PohjoisPohjanmaan rannikon kirkkohaudoista (Light soils. A study of church burials on the coast of northern Ostrobothnia based on written and material sources). Acta Universitatis Ouluensis B Humaniora 28. Oulu, Finland.

Puputti, Anna-Kaisa

2009 Living with Animals: A Zooarchaeological Study of Urban Human-Animal Relationships in Early Modern Tornio, 1621-1800. Doctoral dissertation, Department of Archaeology, University of Oulu, Oulu, Finland.

Pylkkänen, Riitta

1953 1600-luvun kuolinpukuja Turun tuomiokirkkomuseossa (17th-century funerary 
attire from Turku Cathedral Museum). Turun kaupungin Historiallinen Museo, Turku, Finland.

Pylkkänen, Riitta

1955 Säätyläispuku Suomessa vanhemmalla Vaasaajalla 1550-1620 (High-ranking dress in Finland during the Vasa period 1550-1620). Suomen muinaismuisto-yhdistys, Helsinki, Finland.

Pylkkänen, Riitta

1956 Renessanssin puku Suomessa 1550-1620

(Renaissance dress in Finland 1550-1620). WSOY, Helsinki, Finland.

Pylkkänen, Riitta

1970 Barokin muotipuku Suomessa 1620-1720

(Baroque-mode dress in Finland 1620-1720).

Suomen muinaismuisto-yhdistys, Helsinki, Finland.

Pylkkänen, Riitta

1982 Säätyläisnaisten pukeutuminen Suomessa 1700-luvulla (Clothing of higher-ranking women in Finland during the 18th century). Suomen muinaismuisto-yhdistys, Helsinki, Finland.

Regnard, Jean F.

1982 Retki Lappiin (A trip to Lapland), M. ItkonenKaila, translator. Otava, Helsinki, Finland.

Resnick, Donald, and Gen Niwayama

1976 Radiographic and Pathologic Features of Spinal

Involvement in Diffuse Idiopathic Skeletal Hyperostosis (DISH). Radiology 119(3):559568.

Rogers, Juliet, and Tony Waldron

2001 DISH and the Monastic Way of Life. International Journal of Osteoarchaeology 11(5):357-365.

Ruff, Christopher B., Markku Niskanen, Juho-Antti Junno, and $\mathrm{P}$. Jamison

2005

Body Mass Prediction from Stature and Bi-Iliac Breadth in Two High Latitude Populations, with Application to Earlier Higher Latitude Humans. Journal of Human Evolution 48(4):381-392.

Saari, Antti, Ulla Sankilampi, Marja-Leena Hannila, Vesa Kiviniemi, Kari Kesseli, and Leo Dunkel

2011 New Finnish Growth References for Children and Adolescents Aged 0 to 20 Years: Length/ Height-for-Age, Weight-for-Length/Height, and Body Mass Index-for-Age. Annals of Medicine 43(3):235-248.

Salmi, Anna-Kaisa

2011 Riistaa, Kalaa ja Konttiluita-Pohjois-Suomen Maaseudun Ruokakulttuurista n. 1400-1700 AD (Game, fish and tibia - about food culture in the north Finnish countryside ca. A.D. 14001700). In Harmaata näkyvissä-Kirsti Paavolan juhlakirja, Janne Ikäheimo, Risto Nurmi, and Reija Satokangas, editors, pp. 221-236. University of Oulu, Oulu, Finland.
Salmi, Anna-Kaisa, and Tiina Kuokkanen

2014 Bones, Buttons and Buckles: Negotiating Class and Bodily Practices in Early Modern Oulu. Post-Medieval Archaeology 48(1):182-206.

Salo, Kati Hannele

2016 Health in Southern Finland: Bioarchaeological Analysis of 555 Skeletons Excavated from Nine Cemeteries (11th-19th Century AD). Doctoral dissertation, Department of Philosophy, History, Culture and Art Studies, University of Helsinki, Helsinki., Finland. HELDA: Helsingin yliopisto/Helsingfors universitet/University of Helsinki < https://helda .helsinki.fi/handle/10138/163042>. Accessed 25 August 2020.

Schoeninger, Margaret J., and Michael J. DeNiro

1984 Nitrogen and Carbon Isotopic Composition of Bone Collagen from Marine and Terrestrial Animals. Geochimica et Cosmochimica Acta 48(4):625-639.

Scholliers, Peter

2001 Meals, Food Narratives, and Sentiments of Belonging in Past and Present. In Food, Drink and Identity. Cooking, Eating and Drinking in Europe Since the Middle Ages, P. Scholliers, editor, pp. 3-22. Berg, Oxford, UK.

Schulting, Rick J.

1998 Slighting the Sea: Stable Isotope Evidence for the Transition to Farming in Northwestern Europe. Documenta Praehistorica 25:203-218.

Schurr, Mark R.

1997 Stable Nitrogen Isotopes as Evidence for the Age of Weaning at the Angel Site: A Comparison of Isotopic and Demographic Measures of Weaning Age. Journal of Archaeological Science 24(10):919-927.

Spencer, Rosa K.

2008 Testing Hypotheses about Diffuse Idiopathic Skeletal Hyperostosis (DISH) Using Stable Isotope and aDNA Analysis of Late Medieval British Populations. Doctoral dissertation, Department of Archaeology, Durham University, Durham, UK. Durham e-theses, Durham University <http://etheses.dur.ac .uk/1339/>. Accessed 24 August 2020.

Suomela, Jenni A., Krista Vajanto, and R. Räisänen

2017 Seeking Nettle Textiles - Utilizing a Combination of Microscopic Methods for Fibre Identification. Studies in Conservation 63(7):412-422. Taylor \& Francis Online <https://www.tandfonline.com/doi/ full/10.1080/00393630.2017.1410956>. Accessed 24 August 2020.

Talve, Ilmar

1989 Kalmisto-Hautausmaa-Kirkkotarha (Graveyard-cemetery-churchyard). In Elämän Merkit, Vuosikirja 38, M. Taipale and E. Vanhalukkarla, editors, pp. 55-75. Turun arkkihiippakunta, Turku, Finland. 
Tranberg, Annemari

2011 Kasvimaiden historiaa Pohjois-Pohjanmaan Rannikolla ja Peräpohjolassa 1500-luvulta 1800-luvulle (The history of garden plots on the shores of northern Ostrobothnia and Norrbotten). In Harmaata näkyvissä-Kirsti Paavolan juhlakirja, Janne Ikäheimo, Risto Nurmi, and Reija Satokangas, editors, pp. 237-250. University of Oulu, Oulu, Finland.

Väänänen, Kyösti

2011a Rungius, Nicolaus Matthiae (noin 1560-1629). Turun hiippakunnan paimenmuisto 15541721-verkkojulkaisu (Rungius, Nicolaus Matthiae [ca. 1560-1629]. Turku Diocese notes 1554-172-online publication). Suomalaisen Kirjallisuuden Seura, Studia Biographica 9. Helsinki, Finland. Biografiakeskus, Suomalaisen Kirjallisuuden Seura $<$ https://kansallisbiografia.fi/ paimenmuisto/henkilo/2153>. Accessed 25 August 2020.

Väänänen, Kyösti

$2011 b \quad$ Ruuth, Simon Nicolai (K 1615). Turun hiippakunnan paimenmuisto 1554-1721verkkojulkaisu (Ruuth, Simon Nicolai [d. 1615]. Turku Diocese notes 1554-1721—online publication). Suomalaisen Kirjallisuuden Seura, Studia Biographica 9. Helsinki, Finland. Biografiakeskus, Suomalaisen Kirjallisuuden Seura <https://kansallisbiografia.fi/ paimenmuisto/henkilo/2160>. Accessed 25 August 2020.

Vahtola, Jouko

1997a Keskiaika ja 1500-luku (Middle Ages and the 16th century). In Keminmaan historia, Pentti Koivunen, Jouko Vahtola, Reija Satokangas, and Martti Itkonen, editors, pp. 73-85. Keminmaan kunta, Keminmaa, Finland.

Vahtola, Jouko $1997 \mathrm{~b}$

Vaikea vuosisata (1601-1721) (The difficult century [1601-1721]) In Keminmaan Historia, Pentti Koivunen, Jouko Vahtola, Reija Satokangas, and Martti Itkonen, editors, pp. 86177. Keminmaan kunta, Keminmaa, Finland.

Väre, Tiina

2017

Osteobiography of Vicar Rungius: Analyses of the Bones and Tissues of the Mummy of an Early 17th-Century Northern Finnish Clergyman Using Radiology and Stable Isotopes. Acta Universitatis Ouluensis B Humaniora 150. Oulu, Finland. Jultika: University of Oulu Repository <http:/urn.fi/ urn:isbn:9789526215259>. Accessed 25 August 2020.

Väre, Tiina, Juho-Antti Junno, Jaakko Niinimäki, Markku Niskanen, Sirpa Niinimäki, Milton Núñez, Juha Tuukkanen, Annemari Tranberg, Matti Heino, Sanna Lipkin, Saara Tuovinen, Rosa Vilkama, Timo Ylimaunu, and Titta Kallio-Seppä 2016 Computed Tomography of Mummified Human Remains in Old Finnish Churches, a Case Study: The Mummified Remains of a 17th-
Century Vicar Revisited. Post-Medieval Archaeology 50(2):368-379.

Väre, Tiina, Sanna Lipkin, Jaakko Niinimäki, Sirpa Niinimäki, Titta Kallio-Seppä, Juho-Antti Junno, Milton Núñez, Markku Niskanen, Matti Heino, Annemari Tranberg, Saara Tuovinen, Rosa Vilkama, and Timo Ylimaunu

2016 3-Dimensional Archaeological Excavation of Burials Utilizing Computed Tomography Imaging. In CAA 2015, Keep the Revolution Going. Proceedings of the 43rd Annual Conference on Computer Applications and Quantitative Methods in Archaeology 1, S. Campana, R. Scopigno, G. Carpentiero, and M. Cirillo, editors, pp. 133-142. Archaeopress, Oxford, UK.

Väre, Tiina, Jaakko Niinimäki, Juho-Antti Junno, Milton Núñez, Sirpa Niinimäki, and Markku Niskanen

2016 Suspected Tuberculosis in an Early 17thCentury Northern Finnish Mummy-A Computed Tomography Case Study. International Journal of Paleopathology 14:69-73.

Väre, Tiina, Sirpa Niinimäki, Juho-Antti Junno, Jaakko Niinimäki, Markku Niskanen, and Milton Núñez

2011 Computed Tomography in Aid of Osteoarchaeology_A Case Study of Mummified Remains of Vicar Nikolaus Rungius. Fennoscandia Archaeologica 28:8588.

Väre, Tiina, Milton Núñez, Jaakko Niinimäki, Juho-Antti Junno, Sirpa Niinimäki, Rosa Vilkama, and Markku Niskanen

2015 Fame after Death: The Unusual Story of a Finnish Mummy and Difficulties Involving Its Study. Thanatos 4(2):69-77.

Väre, Tiina, Rosa Vilkama, Sirpa Niinimäki, Markku Niskanen, Milton Núñez, Jaakko Niinimäki, and Juho-Antti Junno

2017 Computed Tomography Analysis of Dental Health of a Northern Finnish Early 17thCentury Vicar. Faravid 43:5-20.

Verlaan, Jorrit-Jan, F. Cumhur Öner, and George J. Maat 2007 Diffuse Idiopathic Skeletal Hyperostosis in Ancient Clergymen. European Spine Journal 16(8):1129-1135.

Vilkama, Rosa, Ritva Kylli, and Anna-Kaisa Salmi

2016 Sugar Consumption, Dental Health and Foodways in Late Medieval Iin Hamina and Early Modern Oulu in Northern Finland. Scandinavian Journal of History 41(1):2-31.

Vilkuna, Kustaa

1951 Kemin Sihtuna ja Ruotsin Sigtuna. Kemin kotiseutu- ja museoyhdistys (Kemi Sihtuna and Swedish Sigtuna. Kemi Home Region and Museum Association). Jatuli 3:7-11.

Vilkuna, Kustaa

1974 Lohi. Kemijoen ja sen Lohenkalastuksen Historia (Salmon. The history of salmon fishing in the Kemijoki River). Otava, Helsinki, Finland.

Virkkunen, Artturi H.

1919 Oulun Kaupungin Historia I, Kaupungin Alkuajoilta Isonvihan Loppuun (The history of 
the town of Oulu I, from the beginning to the end of the Great Northern War). Kirjola Oy, Oulu, Finland.

Virrankoski, Pentti

1973 Pohjois-Pohjanmaan ja Lapin historia III, Pohjois-Pohjanmaa ja Lappi 1600-luvulla (History of northern Ostrobothnia and Lapland III, northern Ostrobothnia and Lapland in the 17th century). Pohjois-Pohjanmaan, Kainuun ja Lapin makuntaliittojen yhteinen historiatoi mikunta, Oulu, Finland.

Waldron, Tony

1985

DISH at Merton Priory: Evidence for a 'New' Occupational Disease? British Medical Journal 291(6511):1762-1763.

Waldron, Tony 2009

Paleopathology. Cambridge University Press, Cambridge, UK. Academia <http://www .academia.dk/BiologiskAntropologi/Paleopatologi/ PDF/Palaeopathology_Cambridge_Manuals in

Weber, Max _Archaeology_.pdf $>$. Accessed 25 August $20 \overline{20}$.

1978 Economy and Society. An Outline of Interpretive Sociology. Guenther Roth and Claus Wittich, editors, Ephraim Fischoff, translator. University of California Press, Berkeley.
Wirilander, Kaarlo

1974

Herrasväkeä. Suomen säätyläistö 1721-1870

(Gentry. Finnish upper classes 1721-1870).

Suomen historiallinen seura, Historiallisia tutkimuksia 93. Helsinki, Finland.

Wright, Erik Olin

1993 Class Analysis, History and Emancipation. New Left Review, 1st ser., 202:15-35.

Wurst, LouAnn

2006 A Class All Its Own: Explorations of Class Formation and Conflict. In Historical Archaeology, Martin Hall and Stephen W. Silliman, editors, pp. 190-206. Blackwell, Oxford, UK.

Ylimaunu, Juha 2000

Itämeren Hylkeenpyyntikulttuurit ja Ihminenhylje suhde (Seal-hunting cultures and human/ seal relations on the Baltic Sea). Suomalaisen Kirjallisuuden Seura, Helsinki, Finland.

Publisher's Note Springer Nature remains neutral with regard to jurisdictional claims in published maps and institutional affiliations. 